\title{
Teaching English Literature in the 'Contact Zone': Speaking back to 'Official Nationalism'
}

\author{
Desvalini Anwar \\ English Deparment \\ Universitas Negeri Padang \\ desvalinianwar@yahoo.co.id
}

\begin{abstract}
The concept of a national identity is 'dialogical' (Bahktin, 1981) emerging out of a heteroglossic environment, and so means different things to different people. This means that nationalism is not something natural, as though a feeling of national identity and belonging simply inheres within people, but that it is constructed through language. When Suharto and his regime were still ruling Indonesia, they applied what Anderson (1991) called 'official nationalism' in order to suceeed his 'unity in diversity project'.The implementation, however, was full of contradictions because it was in conflict with the nature of the heterogeneity that made up the Indonesian communities. The New Order's nationalism project was clearly an attempt to maintain order and security in order to shore up his power rather than to explore or understand the differences that make up this vast diverse nation. The fall of Suharto in 1998 was then greeted as opening up the possibility to create a free and democratic society. Suharto's resign was also seen by people working within English literary studies in universities in Indonesia as a momentum to grapple further with alternative discourses of identity. Teaching English literature in this context should then mean providing our students with wider opportunities to study in 'the contact zone' (Pratt', 2008), allowing learning at the interfaces between languages and cultures in order to transcend and to speak back to the hierarchies implied by the dominance or hegemony of global English and its colonial legacy.
\end{abstract}

Keywords-official nationalism, heteroglossic, contact zone, identity, colonial legacy, to speak back

\section{THE POLITICS OF IMAGINING INDONESIA DURING THE NEW ORDER}

When Suharto and his New Order were still ruling Indonesia, they applied what Benedict Anderson (1991) called as 'official nationalism'. Parker (2003, p. 246) views this nationalism project as Suharto's attempt 'to maintain order and security' in order to shore up his power, rather than to explore or understand the differences that make up this vast diverse nation. No wonder that despite seventy years of independence from the Dutch colonialism, it is still said that mental penjajah or colonial mentality is still ruling the nation. This 'die-hard mentality' as Anggraeni (2001) puts it, has now been passed down from one generation to another and is now becoming even more visible in the challenges faced by the English language and literature teachers in Indonesia in their efforts to provide meaningful education for their students vis-à-vis the globalizing economic, social and cultural pressures that are now 'crossing national boundaries with increasing ease' (Parr, Phan, Faine, \& Seddon, 2013, p. 19).

When globalization grew stronger, the New Order regime was clearly seen to have closer contact with western initiatives. For Suharto, the success of his development projects hinged on foreign investment. This resulted in the regime's strong desire to rely on Western knowledge, languages and cultures (Kuswandono et al., 2001). Western languages, particularly English, were not only imported as an addition to the New Order's language policy but were viewed as 'the model for language studies' (Heryanto, 1995, p. 33). This situation means that the regional languages and cultures in Indonesia were faced with even further marginalization. Suharto's language policy then reveals to us that it was not only two-faced but also a mismatch with the Indonesia's linguistic repertoire. The adoption of English as the model for language studies in Indonesia is nonetheless a paradoxical outcome of Suharto's nationalism project as the imposition of English can also mean the imposition of an Anglophone world with little tolerance of other languages and cultural expressions.

\section{ENGLISH LITERATURE TEACHING REDIFINED}

The fall of Suharto's New Order regime in 1998, prior to the monetary crisis which severely hit the nation in 1997 was greeted with euphoria throughout the Indonesian archipelago from Sabang to Merauke as opening up the possibility for creating a free and democratic society. Opportunities emerge to openly discuss experiences, to reveal and question the oppression that had occurred, and to express differences of opinion in ways that were impossible and unthinkable during Suharto's rule. His resignation allows Indonesia's vastly diverse communities to engage with alternative discourses of identity. As a result, new and re-emerging notions of what it means to be Indonesians living in a post-Suharto era emerge in the country. Budiman (2011, p. 6) views 'freedom of the press and regional autonomy for the provinces' as the two issues that highlight the spirit of reformasi in post-Suharto era. This is a defining moment that prompts Indonesian writers to produce literary works as a significant part of the project of nation building. 
Suharto's resign was also seen by people working within English literary studies in universities in Indonesia as an opportunity to grapple further with alternative discourses of identity. The change in the notion 'English' to 'englishes' and 'English literature' to 'Literatures in English (englishes)' has become a topic of discussions amongst English lecturers in Indonesia. Much of the conversation initially intended to provide a space for the peripheral and marginal texts to have their 'voices' heard, still continues to be dominated by western standpoints. This includes further marginalisation of both local languages and literature. Despite the awareness shown by English teachers in Indonesia of issues relating to post-colonialism as an important frame of reference in their efforts to provide a meaningful and relevant education to their students, one still senses a privileging of the 'Western knowledge' (Cavarero, 2000, p. 13) in their work. Scholars such as Canagarajah (1999), Pennycook (1994, 1998), and Phillipson (1992) argue that the privileging of English that is taking place in most parts of the world in the TESOL industry shows that curriculum developers, teachers, and researchers are still working with assumptions about the superiority of the English language and the cultures imported from the English speaking countries. Sumintono (2013) views the overvaluing of English as a mismatch with the nature of the linguistic repertoire of Indonesia because it has overlooked Bahasa Indonesia and the local languages and cultures. Being placed tightly under the outcomes policy set by the western standards, the capacities of both Indonesian students and teachers are 'stretched to the limit as they endeavor to meet the performance benchmarks imposed on them' (van de Ven \& Doecke, 2011, p. 4; Doecke, 2013).

\section{Teaching English at the Interface Between LANGuage And Cultures: Speaking back to “OfFicial NATIONALISM"}

Postcolonial studies have revealed that the notion of hybridity remains one of the main concerns that postcolonial societies have been grappling with. For a highly polyglot postcolonial society like Indonesia this means that the question of identity remains the focus of attention of this vastly diverse society. In line with Ashcroft et al. (1995), Loomba (1998, p. 206) and Foulcher \& Day (2002) state that in order for former colonies 'to decolonize their imperial languages' is to appropriate them 'for their own non-standard uses' (p. 5). The case with Indonesia is however different, whose colonizer was Dutch. The emergence of Bahasa Indonesia as the language of colonial struggle against the Dutch also raised the question of how this language might be used for literary purposes to imagine the very community that the nationalist movement was trying to put in place. It is worth noting how postcolonial scholarship in Indonesia has also begun to appropriate the translation of Indonesian literary works into English. For postcolonial societies, translations of this kind will contribute to not only the de-privileging of standard English but more importantly to the facilitation of 'a vehicle of cultural communication and perhaps a mode of cultural survival' (Ashcroft et al., 1989, p. 205). The de-privileging of standard English can also be achieved by letting 'untranslated words' (Ashcroft et al., 1989, p. 62) remain in the text.

The question left for us now is how English literature teachers should appropriate their teaching to enable their students to imagine the kind of community that reflects a 'common project for the present and the future' (Anderson, 1999, p. 3). In the context of teaching English literature in Padang, the appropriation can be done by providing our students with a literary education in English that does not simply defer to the western canon but that affirms the need for a hybrid approach to the teaching of literatures in English, embracing postcolonial literatures rather than English literature as it is traditionally understood. I then argue that English literature teachers in Padang should see themselves as working at the interfaces between Bahasa Indonesia and English, not to mention Minang and other languages and dialects, transcending the hierarchies implied by global English and its colonial legacy as well as a variety of English translations rather than imagining that we are obliged to aim for some kind of native-speaker -like proficiency and all that this entails. It is through embracing diversity that the young people in our care would learn to be larger in term of their capacity and be more open-minded than they thought they could be.

\section{References}

Anderson, B. (1991). Imagined Communities, Reflection on the Origin and Spread of Nationalism, revised edition. London and New York. Verso.

Anderson, B. (1999). Indonesian Nationalism Today and in the Future.Indonesia, (67): 1-11 Southeast Asia Program Publications at Cornell University. Retrieved from http://www.jstor.org/stable/3351374

Anggraeni, D. (2001).The die-hard colonial mentality. The Jakarta Post. Retrieved from http://www.thejakartapost.com/news/2001/02/04/the-diehard-colonial-mentality.html

Ashcroft, B., Griffiths, G., \& Tiffin, H. (1989) (2 ${ }^{\text {nd }}$ ed.). The Empire Writes Back: Theory and Practice in Post-Colonial Literatures. London: Routledge.

Ashcroft, B., Griffiths, G., \& Tiffin, H. (1995). The post-colonial studies reader. London: Routledge.

Bakhtin, M. M. (1981). The dialogic imagination: Four essays (M. Holquist, Ed.; C.

Emerson \& M. Holquist, Trans.). Austin, TX: University of Texas Press.

Budiman, M (2011). Re-imagining the Archipelago: The Nation in Post-Suharto Indonesian Women's Fiction, (doctoral thesis). Avalaible from

https://open.library.ubc.ca/cIRcle/collections/ubctheses/24/items/1.007179

Canagarajah, A. S. (1999). Resisting linguistic imperialism. Oxford: Oxford University Press. 
Cavarero, A. (2000). Relating Narratives: Storytelling and Selfhood, (with an introduction by P.A. Kottman, Trans.). London and New York: Routledge.

Doecke, B. (2013) Storytelling and Professional Learning, English in Australia, 48 (2), 11-21. Retrieved from http://search.informit.com.au/fullText;dn=568065950763619;res=IELHSS

Foulcher, K. \& Day, T. (2002). Clearing a space: Postcolonial readings of modern Indonesian literature (Eds). Leiden. KITLV Press.

Heryanto, A. (1995). Language of development and development of language: The case of Indonesia. Pacific Linguistics Series D, no. 86. Canberra: Dept. of Linguistics, Research School of Pacific and Asian Studies, Australian National University.

Kuswandono. P., Gandana. I., \& Rohani. S., (2011). Revisiting Local Wisdom: Efforts to Improve Education Quality in Indonesia, paper presented at the AARE Annual Conference, Hobart, 2011. Retrieved from http://www.aare.edu.au/data/publications/2011/aarefinal00625.pdf

Loomba, A. (1998). Colonialism/postcolonialism. London/New York: Routledge

Parker, L. (2003).From subjects to citizens: Balinese villagers in the Indonesian nation-state Copenhagen, Nordic Institute of Asian Studies Press.

Parr, G., Phan, H.L., Faine, M., \& Seddon, T. (2013).Globalisation and its challenges for History teaching.AGORA. History teachers' association of Victoria, 48 (2): 18-26 Retrieved from http://search.informit.com.au/fullText;dn=422374748495753;res=IELHSS

Pennycook, A. (1994). The Cultural Politics of English as an International Language. London: Longman.

Pratt, M. L. (1991). Arts of the Contact Zone. In P. Franklin (Ed.), Profession 91: 33-40. New York: Modern Language Association of America. Retrieved from http://www.nieuweleescultuur.ugent.be/files/meer_lezen2_pratt.pdf

Pratt, M. L. (2008) Imperial Eyes: Travel Writing and Transculturation (2nd ed.). London: Routledge.

Sumintono, B, (2013). RSBI: Problems seen in hindsight. Retrieved from http://www.thejakartapost.com/news/2013/01/11/rsbi-problems-seen-hindsight.html

van de Ven, P.H. \& Doecke, B. (eds) (2011). Literary Praxis: A Conversational Inquiry into the Teaching of Literature. Rotterdam: Sense Publisher 